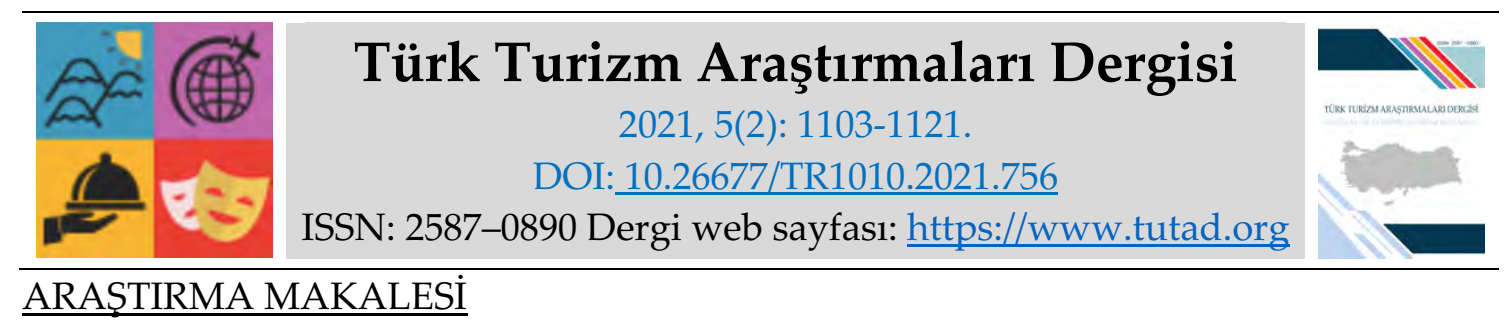

\title{
AHP Yöntemi ile Seyahat Acentalarının Ekoturizm Kriterleri Algılarının Tespiti: Giresun Örneği*
}

Hatun İŞLER, Yüksek Lisans Öğrencisi, Giresun Üniversitesi, Sosyal Bilimler Enstitüsü, Giresun, e-posta: hatunhilk@gmail.com

ORCID: https://orcid.org/0000-0001-9065-1066

Doç. Dr. Hakan AKYURT, Giresun Üniversitesi, Bulancak Kadir Karabaş Uygulamalı Bilimler Yüksekokulu, Giresun, e-posta: hakan.akyurt@giresun.edu.tr

ORCID: https://orcid.org/0000-0002-6522-684X

Öz

Çalışmanın temel amacı, seyahat acenta yöneticilerinin algılarında ekoturizme etki eden kriterlerden hangilerinin daha önemli olduğunun tespit edilmesi olarak belirlenmiştir. Ekoturizme etki eden kriterlerin önem derecesine göre sıralanması ve destinasyonlarda üzerinde durulması gereken unsurların belirlenmesi hedeflenmektedir. Özellikle de Doğu Karadeniz bölgesinde önem arz eden ekoturizm faaliyetlerinin şekillendirilmesi açısından, turistik hareketlere yön veren seyahat acenta yöneticilerinden elde edilen verilerin, bölgenin ekoturizm talebine olumlu olarak yansıması hedeflenmektedir. $\mathrm{Bu}$ nedenle, çalışmada ekoturizm destinasyonlarından biri olan Giresun ilindeki seyahat acentalarının yöneticileri hedef kitle olarak alınmıştır. Çalışmada, çok kriterli karar verme yöntemlerinden biri olan Analitik Hiyerarşi Süreci yöntemi kullanılmıştır. Çalışma sonuçlarında, seyahat acenta yöneticilerinden elde edilen verilerin analizleri ışığında, Giresun ili ekoturizm destinasyonlarında önem derecesine göre kriterler sırası ile güvenlik, turizm tesisleri, doğal yaşam, kültürel yapı, ulaşım, coğrafi özellikler, altyapı, iklim ve fiyat olarak sıralanmıştır. Ekoturizm destinasyonlarına etki eden en önemli kriterin güvenlik olduğu belirlenmiştir.

*Çalışma, Hatun İŞLER'in Yüksek Lisans tezinden üretilmiştir.

Anahtar Kelimeler: Ekoturizm, Seyahat Acentası, Analitik Hiyerarşi Yöntemi, Giresun İli Turizmi.

Makale Gönderme Tarihi: 05.01.2021

Makale Kabul Tarihi: 02.06.2021

\section{Önerilen Atıf:}

İşler, H. ve Akyurt, H. (2021). AHP Yöntemi ile Seyahat Acentalarının Ekoturizm Kriterleri Algılarının Tespiti: Giresun Örneği, Türk Turizm Araştırmaları Dergisi, 5(2): 1103-1121.

(c) 2021 Türk Turizm Araştırmaları Dergisi. 


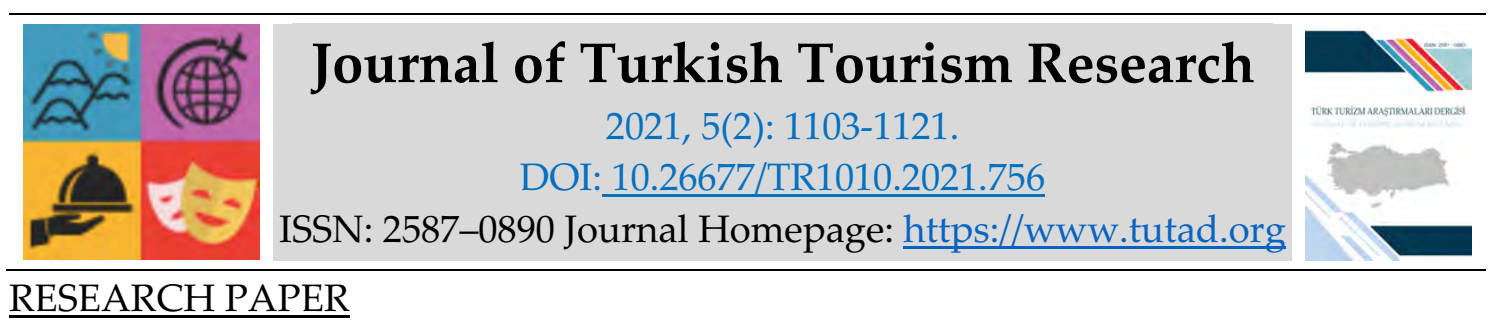

\title{
Determination of the Travel Agencies' Perceptions of Ecotourism Criteria with AHP Method: The Case of Giresun
}

Hatun İŞLER, MSc. Student, Giresun University, Social Sciences Institute, Giresun, e-mail: hatunhilk@gmail.com

ORCID: https://orcid.org/0000-0001-9065-1066

Associate Prof. Dr. Hakan AKYURT, Giresun University, Bulancak Kadir Karabaş School of Applied Sciences, Bulancak, Giresun, e-mail: $\underline{\text { hakan.akyurt@giresun.edu.tr }}$

ORCID: https://orcid.org/0000-0002-6522-684X

\begin{abstract}
The main purpose of the study is to determine which of the criteria affecting ecotourism are more important in the perceptions of travel agency managers. It is aimed to rank the criteria that affect ecotourism according to their importance and to determine the factors that should be focused on in destinations. Especially in terms of shaping ecotourism activities, which are important in the Eastern Black Sea region, it is aimed that the data obtained from travel agency managers who direct touristic movements will reflect the region's ecotourism demand positively. For this reason, travel agency managers of Giresun province, one of the ecotourism destinations, were taken as the sampling group in the study. The Analytical Hierarchy Process method, one of the multicriteria decision-making methods, was used in the study. In the study results, in the light of the analysis of the data obtained from the travel agency managers, the criteria for ecotourism destinations in Giresun province are listed as security, tourism facilities, natural life, cultural structure, transportation, geographical features, infrastructure, climate and price, respectively. It has been determined that the most important criterion affecting ecotourism destinations is security.
\end{abstract}

Keywords: Ecotourism, Travel Agency, Analytical Hierarchy Method, Giresun Province Tourism. Received: 05.01.2021

Accepted: 02.06.2021

\section{Suggested Citation:}

İşler, H. and Akyurt, H. (2021). Determination of the Travel Agencies' Perceptions of Ecotourism Criteria with AHP Method: The Case of Giresun, Journal of Turkish Tourism Research, 5(2): 11031121.

(C) 2021 Türk Turizm Araştırmaları Dergisi. 


\section{Gíriş}

Alternatif turizm çeşitlerinden olan ekoturizm, küçük gruplar halinde, doğaya ve kültürel değerlere bağlı rekreasyonel faaliyetleri sunmakta turistlere iyi vakit geçirme ve yeni tatil olanaklarını keşfetme olanağı sağlamaktadır. 2019 yılının sonlarında Çin'in Wuhan şehrinde ortaya çıkarak Dünya'yı etkisi altına alan COVID-19 salgınıyla birlikte insanların kalabalık ortamlardan uzak durma eğilimi ekoturizme yönelmeleri için önemli bir fırsat haline gelmiştir. Ekoturizm, şehri kalabalığından uzaklaşarak, açık alanlarda, doğayla bütünleşen tatil yapmak isteyen turistlere daha kontrollü ve sağlıklı tatil fırsatı sunmaktadır. Bu nedenle, günümüz şartlarında turizm endüstrisinden faydalanmak isteyen destinasyonların ekoturizmi değerlendirmeleri gerekmektedir.

Ekoturizm temelde çevrenin korunmasını amaçlı faaliyetlerden oluşmaktadır. Öncelikle doğaya yönelik zararın en az seviyede olmasını savunan, yerel halka en üst düzeyde sosyal kültürel ve ekonomik fayda sağlamasını öngören bir turizm felsefesine dayanmaktadır. Ekoturizm, korunması gereken doğal alanların turizm faaliyeti içinde negatif etkilerini en aza indirgeyerek, özellikle korunan yerlerde doğal ve kültürel seyahatler gerçekleştirmekle birlikte, farklı kültür ve gelenekleri gözlemleme imkanı sunmaktadır. Ekoturizm geleneksel kültürlerin unutulmasını önlerken onların yeni nesillere aktarılmasını sağlamaktadır (Akova, 2016: 319).

Destinasyonda sürdürülen turizm faaliyetlerinin planlanması ve pazarlanmasında seyahat acentalarının turist davranışlarına yönelik düşünceleri son derece önemli bir yer tutmaktadır. Bu bağlamda, turizm sektörünün önemli yapıtaşlarından biri olan seyahat acentalarının rolü önem arz etmektedir. Ekoturizm endüstrisinin en önemli paydaşlardan olan seyahat acentaları, turist beklenti ve taleplerine yönelik hazırladıkları turizm stratejilerini belirlemekte ve uygulamaktadır. Acentalar, turist beklentilerine cevap verebilmek için turizme yönelik hazırladıkları planlamalarında destinasyonun imkan ve ihtiyaçlarının tespit edilmesinde etkin rol oynamaktadır. Bu bağlamda, ekoturizm destinasyonunda turizm faaliyetlerinin geliştirilebilmesinde seyahat acentalarının destinasyon hakkında düşüncelerine önem verilmektedir.

Ekoturizmin son yıllarda turizm çeşitleri içinde daha da popüler olması nedeni ile hem eğitim anlamında hem de sektörel yatırımlar bakımından önemli hale geldiği görülmektedir. Ekoturizm destinasyonları, turizmin ülke geneline yayılması ve turistik gelirlerin arttırılması açısından önemli bir turizm çeşididir (Atay ve Altınışık, 2017: 112). Ancak, ekoturizm destinasyonlarındaki temel sorun, bu destinasyonlara etki eden kriterlerin net olarak ortaya konulamamasindan kaynaklanmaktadır. Farklı bölgelerdeki ekoturizm destinasyonlarında kriterlerin aynı olması beklenemez ve her bir destinasyonun kendisine göre farklı özellikleri olacağından, bu destinasyonlara etki eden faktörlerinde farklı olma ihtimali kuvvetlidir. Çalışma ile ortaya konulmak istenen, ekoturizm destinasyonlarına etki eden kriterlerin net ve açı şekilde ortaya çıkarılması ve Giresun ili Seyahat Acenta yöneticileri bakış açılarına göre bu sorunsala farklı bir yaklaşım sunmaktır.

\section{Ekoturizm Kavramı ve Amaçları}

Ekoturizmin temelleri 18.yüzyıl sonlarında Alexander Von Humboldt tarafından doğanın yapısını ve işleyişinin anlaşılabilmesi için doğayı keşfetmek üzere seyahatler düzenlenmesi gerektiği yönündeki tavsiyesiyle atılmıştır. 1960'lı yıllarda doğaya dönüş hareketleriyle birlikte bilim insanları tarafından farklı söylemler ortaya çıkmıştır. Ekoturizm terimi 1978 yılında Kenton Miller tarafından ilk kez kullanılmış olup, terimi açıklayan en yaygın tanım ise 1983 yılında Hector Ceballos Lascurain tarafından yapılmıştır (Belber, 2018: 2-3). Lascurain tanımında 
ekoturizm; "geçmişten günümüze kadar gelen kültürel değerlere, el değmemiş veya kısmen koruma altına alınmış doğal alanlarla ve bu alanların içindeki yaban hayatını keşfetme, izleme, deneyimleme gibi faaliyetler sunan ve de bir amaç doğrultusunda yapılan ziyaretler" olarak ifade edilmektedir (Ceballos-Lascurain, 1987: 13).

Ekoturizm en genel tanımı ile, "öncelikle doğayı deneyimlemeye ve öğrenmeye odaklanan, genellikle doğal alanlarda oluşan ve bu alanların koruyan veya korunmasına katkıda bulunan, etik olarak tüketime yönelik değil, yerele fayda sağlayan, sürdürülebilir doğal kaynak temelli turizm" olarak ifade edilmektedir (Fennell, 1999: 43). Farklı bir ifade ise ekoturzmi, "deniz, kum, güneş gibi standart tatil anlayışının yerine ziyaretçilerin boş zamanlarını dinlenerek, kültürleri tanıyarak doğal yaşam içinde vakit geçirdikleri rekreasyon faaliyetleri" olarak açıklamaktadır (Bayer, 1992: 178).

Turizmin istenmeyen etkilerini azaltarak, gezilecek yere karşı duyarlı olunmasını hedefleyen ekoturizm, hassas ekosistemlere geziler düzenleyerek bölgenin doğal güzelliklerini ve ziyaretçilerin gözlemlemesi yoluyla bilgi ve deyimlerine katkı sağlayan etkinlikleri içermektedir (Akova, 2016: 320). Ekoturizm faaliyetleri gerçekleştirirken ziyaretçi gruplarındaki katılımcı sayılarını azaltarak doğaya ve yerel bölgeye verilen zararı en aza indirgemeyi hedefler ve yılın belli bir sezonunda faaliyet göstermeyip yılın genelinde hizmet vermektedir (Çeken, 2016: 142). Ekonomiye katkı sağlamak amacıyla çiftçilik, balıkçılık ve sosyal etkinlikler gibi geleneksel faaliyetlerden faydalanarak ekoturistleri yerel halkla buluşturmaktadır. Ekoturizm alanlarındaki etkinliklere katılan ekoturistlerin doğal alanları görme beklentileri karşısında, yerel halkın da desteğiyle iki taraflı etkileşim sonucunda gelişim sağlamaktadır (Fennell, 1999: 40).

Ekoturizm kavramının ilk gündeme geldiği günden bugüne kadar birçok tanımının yapılmış olmasına rağmen, henüz standartlaşmış bir tanımı yapılmamıştır. Tanımsal bütünselliğin sağlanamamasının temel nedeninin, ekoturizme karşı diğer bilim dalları arasındaki görüş farklılıklarından kaynaklandığı iddia edilmektedir. Kavram hakkında fikir birliği olmamasının başlıca sebebi; ekonomik, çevresel ve pazarlama konularında farklı değerlendirmelerin söz konusu olmasıdır. Kavram, ekonomistler tarafından yerel ekonomide fayda yaratma ve istihdam oluşturma aracı olarak değerlendirilmektedir. Turizm işletmeleri yöneticileri ekoturizmi, pazarlama aracı olarak tanımlamakta ve çevre koruma amaçlı kurulmuş olan sivil toplum kuruluşları tarafından ise, doğal alanların korunmasındaki unsurlar olarak ifade edilmektedir (Türkmen, 2018: 130).

Bu kapsamda ekoturizmin amacı, ziyaretçilerin talepleri doğrultusunda öğrenme, yardımlaşma, doğaya karşı duyarlı olma, doğanın değerini bilme olarak ifade edilmektedir. Ekoturizmin ekonomik anlamda amacı, yeni kar sahaları oluşturmaktır. Endüstri açısından amacı ise, insanların doğaya karşı nasıl tutum sergilediği ve doğaya yönelik davranış biçimlerine bağlı olarak değişim göstermektedir (Erdoğan, 2003: 112).

Ekoturizm, günümüz salgın koşulları düşünüldüğünde, turistlerin kalabalık ortamlardan uzaklaşması ve yeni destinasyonlarda doğal alanlara yönelmesi nedeni ile daha da önem kazanmaktadır. Son on yılda artan ilgiye ve talebe rağmen, özellikle dünya genelindeki salgın ve benzeri durumlar, ekoturizmin gelişimini ve önemini arttırmaktadır. Bu salgının sona ermesi için çalışmaların hız kazanmasına ve salgının azalacağına yönelik fikirlerin belirtilmesine rağmen, insanların algılarında kalabalık olmayan ve de doğa ile baş başa kalabilecekleri tatil seçenekleri herzaman devam edecektir. Bu nedenle, ekoturizm destinasyonlara olan talebin gelecek yıllarda artarak devam etme ihtimali yüksektir. 


\section{Ekoturizmin Özellikleri ve Faaliyet Türleri}

Ekoturizm, diğer turizm çeşitlerine göre yapısı gereği farklı özellikler ortaya koymaktadır. Doğaya, çevresel unsurlara ve diğer canlıların yaşam haklarına ilişkin temel kuralları olan ekoturizm, insanların turizm aktivitelerinde farklılıklar ortaya koymaktadır. Bu farklılıklar ekoturizmin kendine has özelliklerinden kaynaklıdır. Bu nedenle, ekoturizmin özelliklerinin belirtilmesi ve iyi anlaşılması önem arz etmektedir.

Genel olarak ekoturizmin özelliklerini metindeki gibi özetlemek mümkündür (Zeppel, 2006: 14): Uzak bölgeler, korunan alanlar, özel rezervler gibi doğal yerlere seyahatleri kapsamaktadır. Tesislerin ve turistlerin ekolojik / kültürel etkilerini en aza indirmektedir. Turistlere ve bölge sakinlerine eğitimli rehberler tarafından çevre eğitimi verilmesi çevresel ve kültürel farkındalık yaratmaktadır. Turizm çevre koruma, eğitim ve araştırma fonları, park giriş ücretleri, turizm vergileri ve harçlar, koruma bağışları gibi unsurlar koruma için doğrudan finansal faydalar sağlamaktadır. Park gelir paylaşımı, topluluk turizmi imtiyazları ve ortaklıkları yerel halk için finansal destek ve yetkilendirme yapmaktadır. Yerel geleneklere, kıyafet kurallarına ve sosyal normlara kültürel olarak saygılı, ev sahibi ülkelere duyarlıdır. İnsan haklarını ve demokratik hareketleri desteklemenin yanı sıra sosyal ve politik durumu göz ardı etmemektedir.

Bununla birlikte, yukarıda belirtilen özelliklerin bağlı olduğu temel ilkeler bulunmaktadır. Bu ilkeler çerçevesinde ekoturizm faaliyetlerinin ve hedeflerinin daha iyi anlaşılması mümkün olacaktır. Ekoturizmin genel ilkeleri ise sırası ile aşağıdaki gibi ifade etmek mümkündür (Björk, 2000). Ekoturizm sürdürülebilir olmalı, doğal kaynaklar bilinçli kullanılmalıdır. Çevre, turizme dahil olan faktörlerin davranışlarını etkilemektedir. Uzun vadeli planlama odağı olmalıdır. Ekoturizm yerel ekonomi ve yerel kalkınmayı desteklemelidir Yerel alanlarda gelişmeyi etkilemektedir. Ekoturizm dinamik olmalı süreklik sağlamalıdır. Ekoturizm eğitici olmalıdır. Ekoturizmde ahlaki ve etik yönler dikkate alınmalıdır. Davranış biçimi ile çevresel etik uyum içinde olmalıdır. Ekoturistler doğayı büyük ölçüde kendi şartlarına göre kabul etmelidir. Ekoturizm sosyal, ekonomik, politik veya bilimsel faydalara sık sık bölünmesine rağmen, çevre faaliyetlerine daha fazla katkıda bulunmalıdır. Kaynakların etkin kullanımı hakkında bilinçlendirme yapılmalıdır. Doğa ile iç içe yaşayarak farklı tecrübeler edinilmelidir.

Ekoturizm olgusu, diğer turizm çeşitleri ile kıyaslandığında çok daha fazla emek ve çalışma isteyen birçok unsuru içermektedir. Ekoturizm aktivitelerinin doğa ile birlikte gerçekleştirilmesi nedeni ile hem turizm alanında hem de çevresel unsurlar ve yapılaşmaya ilişkin yasal mevzuatlara tabi olmaktadır. Örneğin, orman alanlarına ilişkin yasal mevzuatlar Orman Bakanlığı tarafından belirlenmektedir. Bu alanlarda ekoturizme yönelik rekreasyon ve diğer turizm aktivitelerini yapmak, ancak bu bakanlık tarafından belirlenen yönetmelik ve yasalar çerçevesinde yapılabilmektedir. Bu nedenle, yasal işleyiş bakımından da farklı kanun ve yönetmeliklerin aşılması ve de daha sonra ekoturizm faaliyetlerinin yapılması mümkün olmaktadır. Bu durum ekoturizmin kendine özgü özelliklerinden ilkini göstermektedir.

Ekoturizmin temel özelliklerinin yanı sıra genel olarak hangi faaliyet türlerini kapsadığını belirtmek gerekmektedir. Şekil 1'de ekoturizmin genel olarak hangi faaliyet türlerini sunduğu belirtilmektedir. Bu faaliyet türleri, öğrenmeye, eğlenceye ve dinlenmeye yönelik olarak farklı turizm aktivitelerini kapsamaktadır. 


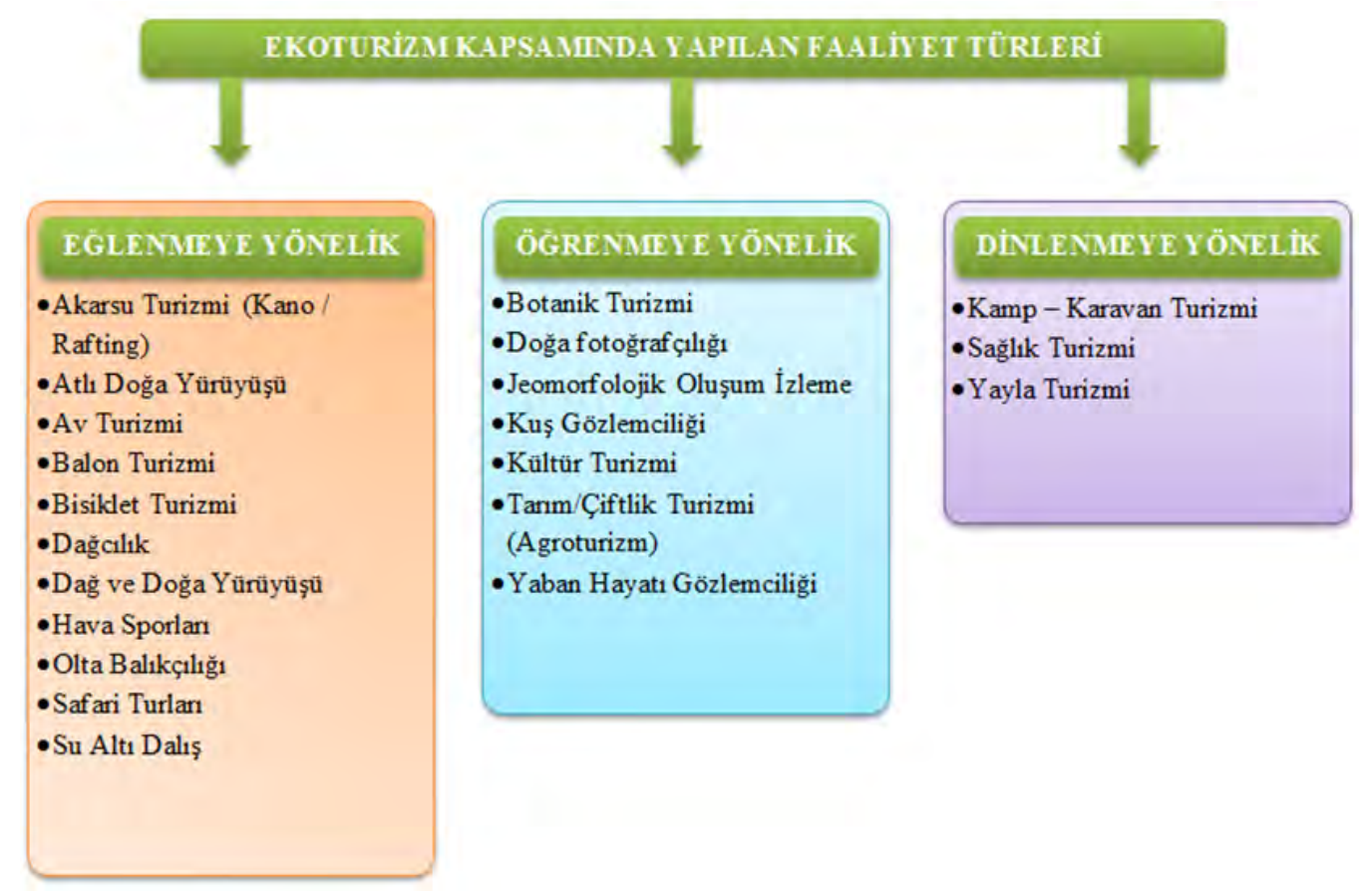

Şekil 1. Ekoturizm kapsamında yapılan faaliyet türleri

Kaynak: Koçan, 2012: 71; Ovalı ve Tachir, 2015: 38; Akyurt, 2019: 357.

Ekoturizm yerel ve kültürel değerlere sahip çıkarak doğal bölgelerin korunmasına katkıda bulunan bir seyahat türü olmasının yanında doğada yapılan etkinliklerin hepsini ekoturizm kapsamında değerlendirmek doğru değildir. Günlük yaşantımız içerisinde herhangi bir faaliyeti gerçekleştirirken, doğada karşılaşılan bir sahneyi fotoğraflamak ekoturizm kapsamında değerlendirilemez. Ekoturizm kapsamında yapılan etkinliklerin kültürel değerlere önem vermesi ve bölge halkının refahına sosyal, kültürel ve ekonomik yönden fayda da yaratıyor olması da beklenmektedir (Darwish ve Burns, 2019: 155).

\section{Turizmde Seyahat Acentasının Rolü}

Turizm sektörü içerisinde dağıtım kanallarının önemi gelişen teknoloji ve iletişim sektörleri ile artmaktadır. İnsanların turizm faaliyetlerine katılmaları bireysel olarak başlayan bir süreç olarak ifade edilse de günümüz turist profili tatillerini garanti altına almak ve paket turlar ile turizm aktivitelerine katılmak istemektedir. Bu nedenle, günümüz turizm faaliyetleri içerisinde seyahat acentaları ve tur operatörlerinin önemi artmıştır. Çalışmanın konusu itibariyle, seyahat acentalarına ekoturizm kapsamında kısaca değinilmesi uygun olacaktır.

Seyahat acentaları, en kısa ifade ile turistler ile destinasyonlar arasındaki konaklama ve tatil seçeneklerini ortaya koyan işletmeler olarak tanımlanabilir. Seyahat acentaları, özellikle turizme artan talep ve turizm yatırımlarının ülkeler içinde artması sonucu ortaya çıkan kurumlardır. İnsanların tatillerini rahat ve planlı şekilde geçirmek amacı ile satın almalarını yaptıkları işletmelerden birisi de seyahat acentalarıdır. Daha önce seyahat etmedikleri ve konaklama yapmadıkları destinasyonda kendilerine güvenli bir tatil ve de seyahat imkanları aramaktadırlar. Bunun sonucu olarak seyahat acentaları, turistlerin tatillerinde ihtiyaç duyacakları tüm faaliyetleri turistlere sunmaktadır. Turistler, ödeyecekleri ücretlerin karşılığını almak istediğinden, memnun kalmadıkları durumlarda verdikleri ücreti iade almak veya farklı tatil seçenekleri arzu etmektedir. Seyahat acentaları, turistleri tatillerine başladıkları ilk aşamadan eve 
dönüş olan son aşamaya kadar her konuda planlama yapmaktadır. Bu nedenle, özellikle internetin yayılması ve satın almalarda kullanılması ile iade koşullarının ve sigorta imkanlarının turistler lehine geliştirilmesi sonucunda seyahat acentalarına olan talep artmaktadır.

Seyahat acentaları, turistlerin seyahatlerine ilişkin tüm unsurları düşünmeye çalışan ve karşılayan ticari işletmeler olarak ifade edilmektedir. Turlar düzenlemek, transfer hizmetleri, konaklama hizmetleri, bilgi akışını sağlamak, kongre veya konferans düzenlemek, araç kiralamak, otobüs veya uçak bileti satmak ve destinasyonların tanıtımları yapmak gibi birçok farklı faaliyeti aynı anda yapabilen işletmelerdir (İçöz, 2000: 47). Seyahat acentaları diğer turizm işletmelerine göre çok daha kompleks işlemler yapmak zorundadır. Turizm işletmelerinin, çeşitlerinin ve destinasyonların artması ile birlikte turistler ile turistik destinasyonlar arasındaki tüm faaliyetleri planlama mecburiyetleri vardır. Bu durum neticesinde seyahat acentalarının faaliyetleri aşağıdaki genel başlıklar atında değerlendirilmektedir (Hacıoğlu, 2000: 178):

- Turizm Ürünleri; turistlerin ihtiyaç ve isteklerine uygun olarak turistik ürünleri hazırlama ve turistlere sunma işlevi yapmaktadırlar. Coğrafik özelliklere ve turist yapılarına uygun olarak seçimler yapmaktadırlar.

- Reklam; acentaları hem destinasyonların hem kendi sundukları hizmetlerin hem de konaklama tesislerinin tanitımlarını yapmaktadır.

- Kişisel Satış; pazarlama çabaları içerisinde önemli bir yeri vardır. Satış personelleri, işletme içinde ve farklı destinasyonlarda satış işlemini bireysel olarak gerçekleştirmektedir.

- Dağıtım İşlevi; maliyetleri azaltarak hedef kitleye yönelik olarak çalışmalar yapmaktadır. Sadece mevcut müşteri üzerinden değil, potansiyel müşteri kitlesine yönelik olarak hizmet sunumu gerçekleştirmektedir.

- Fiyatlama; günümüz maliyet koşullarını ele alarak kararlar alınmaktadır. Paket turları, konaklama, transferler ve diğer turizm aktiviteleri ile bütün olarak fiyatlama yoluna gitmektedirler. Ürün çeşitliliği ve destinasyon farklılıkları nedeni ile fiyatlandırma konusunda benzerlikle söz konusu olmaz. Kar marjı, personel ücretleri, vergiler ve maliyetler fiyatlandırma konusunda temel unsurları oluşturmaktadır.

- İletişim; sunulan tüm hizmetler ve koşullar ancak seyahat acenta personelinin etkili iletişim ve insanlar ile olan diyalogları ile sonuç vermektedir. Bu nedenle, personelin iletişiminin, sunulan ürünler ve piyasadaki rekabet durumu hakkında yetenekli ve de bilgili olması gerekmektedir.

Turizm sektörü içinde seyahat acentalarının rolü her geçen gün daha da önem kazanmaktadır. Sektörün özellikle pandemi sürecinde çok fazla sorun yaşadığı düşünüldüğünde, bu tür dünya genelinde oluşacak olumsuzluklara karşı tedbirlere yönelik çalışmalar yapılması gerekmektedir. Ayrıca, seyahat acentalarında çalışan personelin kalifiye ve uzman olması ancak yeterli turizm eğitimi almış personel ile mümkündür. Konaklama işletmelerini ve destinasyonların tanıtımlarını gerçekleştiren bu işletmelerin, pandemi gibi süreçlerde devlet yönetimleri tarafından desteklenmesi, mevzuat yönünden turizm eğitimi almış personel sayısının arttırılması, gelecekte turistik talebin sürdürülebilir olması bakımından önem arz etmektedir.

\section{YÖNTEM}

\section{Araştırmanın Amacı ve Önemi}

Çalışma, ekoturizm destinasyonlarını etkileyen kriterlerin önem derecesine göre sıralanmasını ve hangi kriterlerin diğerlerinden daha önemli olduğunu ortaya koymayı amaçlamaktadır. Turizm sektöründe turistik talep yaratması, pazarlama araçlarını kullanması ve destinasyonun turizme kazandırılmasında önemli rol oynayan seyahat acenta yöneticilerinin fikirleri 
doğrultusunda bilgiler edinilmesi amaçlanmıştır. Çalışmanın analizi sonucunda elde edilecek bilgiler ile önce Giresun ili ekoturizm destinasyonlarında sonra da diğer bölgelerdeki ekoturizm destinasyonlarında öncelik verilmesi kriterlerin ortaya konulması ve gelecekte yapılacak olan akademik çalışmalara önderlik etmesi hedeflenmektedir.

Literatür taraması sonucu seyahat acentalarının ekoturizm algılamalarına yönelik olarak çalışmaya rastlanmamıştır. Bununla beraber, Erdoğan (2012), çevre duyarlılı̆̆ı ile seyahat acentalarının web siteleri arasındaki ilişkiyi incelemiş, yöntem olarak çok kriterli karar verme yöntemlerinden birini kullanmamıştır. Ayrıca, genel olarak ekoturizm kapsamında değerlendirmeler yapılmamıştır. AHP (Analitik Hiyerarşi Süresi) yöntemi ile seyahat acentalarına yönelik olarak çalışmalarda ise Doğan ve Gencan (2013), bu yöntemle uygun otel seçimine ilişkin çalışma yapmıştır. Ayrıca, Ilgaz Yıldırım ve Güzel (2019), AHP yöntemi ile rehberler üzerine çalışma yapmıştır. Çalışma sonuçları ile benzer konularda yapılan akademik çalışmalar arasındaki ilişkiler incelendiğinde, Ilgaz ve Kozak tarafından 2019 yılında yapılan çalışmada destinasyonun seçiminde AHP yöntemi turistlere uygulanmıştır. Bu çalışma sonucunda sosyal medya unsurlarının en önemli kriterler olduğu sonucu ortaya çıkmıştır. Yapılmış olan bu çalışmanın turistlere uygulanmış olmasından ve destinasyon seçimi ile ilgili bir konu olması nedeni ile bu çalışma ile temel olarak farklılıkları mevcuttur. Sadece kullanılan yöntem açısından benzerlik söz konusudur. Konu bütünlüğü ve uygulama alanları tamamen farklı olarak yapılmıştır. Bir başka benzer çalışmada ise Bunruamkaew ve Murayama tarafından ekoturizm alanlarında sürdürülebilir turizm planlamasına yönelik olarak 2011 yılında çalışma yapılmıştır. Bu çalışmada seyahat acentalarına sorular sorulmuş ve ekoturizm destinasyonlarının planlanmasında hangi faktörlerin etkili olduğu ortaya konulmaya çalışılmıştır. Çalışma sonucunda biyo-çeşitliliği korumak ve turizm yöneticilerinin ekoturizme desteğinin ekoturizm destinasyonlarının sürdürülebilir kalkınması açısından önemli olduğu sonucu ortaya konulmuştur. Ancak bu çalışma da AHP yöntemi kullanılmadığından, bu çalışma ile hem konu bütünlüğü hem de araştırma yöntemi açısından farklılıklar bulunmaktadır. Bununla birlikte, ekoturizm ile ilgili birçok çalışma olmasına rağmen bu çalışmada kullanılan yöntemin farklılığ ve sektör temsilcisi olarak seyahat acenta yöneticilerinin seçilmiş olması nedeni ile çalışma özgün bir niteliğe sahiptir. Geçmişte yapılan çalışmalar ile bu çalışma arasında birebir uyumlu ve benzer bir çalışmaya rastlanamamıştır.

\section{Araştırmanın Evreni ve Örneklemi}

Çalışmanın evrenini Giresun Ill Kültür ve Turizm Müdürlügü’'nün verilerinde yer alan 20 seyahat acentası oluşturmaktadır (Giresun İl Kültür ve Turizm Müdürlüğü, 2021). Giresun ilinde yer alan 20 seyahat acentasından ulaşılabilen 10 acenta ye yöneticiyle yapılan görüşme ve anket uygulaması ise çalışmanın örneklemini oluşturmaktadır. Bu aşamada, seyahat acenta yöneticileri ile yüz yüze görüşmeler yapılmıştır.

Araştırmanın evrenini temsil etmesi bakımından esas alınan unsur, çok kriterli karar verme yöntemlerinde uzman görüşlerinin evreni temsil eden sayıya ilişkin belirtilen ifadelerden alınmaktadır. Çok kriterli karar verme yöntemlerinde uzman görüşlerinin teknik, bilimsel ve uzmanlık alanlarına uygun olarak yapılması durumunda, bir uzman görüşünün bile araştırma evrenini temsil edeceği ifade edilmektedir. Bu kapsamda, Giresun ili seyahat acenta sayısı 20 olarak tespit edilmiş, bunlardan 10 acenta ile anketler gerçekleştirilmiştir. Bu nedenle, diğer sosyal bilimler araştırma yöntemlerinden farklı olarak, AHP yöntemi kurallarına göre araştırma örneklemi evreni temsil etme yeteneğine sahiptir (Erdal ve Korucuk, 2018: 103). 


\section{Araştırmanın Geçerliliği ve Güvenirliliği}

Araştırma da kullanılan kriterler daha önceden yapılmış olan geçerlilik ve güvenilirlik sonuçları elde edilmiş olan çalışmalardan alınmıştır. Bu nedenle, araştırmanın geçerlilik ve güvenilirlik konusunda sorunu bulunmamaktadır. Çalışmada kullanılan anket formu daha önce gerçekleştirilmiş olan çalışmalardan (Bunruamkaew ve Murayama, 2011: 273; Ullah ve Hafiz, 2014: 261; Ilgaz ve Kozak, 2019: 497) derlenen seçim kriterleriyle oluşturulmuştur. Araştırma da seyahat acentası yöneticilerinin ekoturizm anlayışında etkili olan 9 (dokuz) kriter Tablo 1'de belirtilmektedir.

Tablo 1. AHP Ölçeği Temel Kriterler Tablosu

\begin{tabular}{lc}
\hline Kriter & Temel Kriterler \\
\hline 1 & Ulaşım \\
\hline 2 & Fiyat \\
\hline 3 & Doğal Yaşam \\
\hline 4 & İklim \\
\hline 5 & Kültürel Yap1 \\
\hline 6 & Coğrafi Özellikleri \\
\hline 7 & Güvenlik \\
\hline 8 & Altyapi \\
\hline 9 & Turizm Tesisleri \\
\hline
\end{tabular}

Bununla birlikte, AHP analizi güvenirlilik sonucu "CR değeri: 0,0641" olarak belirlenmiştir. Güvenirlilik sonucu 0,1'den küçük çıktığı için çalışmanın analizi güvenilir olarak kabul edilmektedir (Saaty, 1980).

\section{Veri Toplama Yöntemi}

Çalışma, AHP yöntemine uygun olarak hazırlanan anketlerin hazırlanması ve Giresun ili seyahat acentası yöneticilerine uygulanmasıyla başlatılmıştır. Söz konusu kriterler kendi arasında ikili karşılaştırmalar yapılarak, Analitik Hiyerarşi Süreci Yöntemi ile analiz edilmiştir. Kriterlerin birbiri arasındaki önem dereceleri belirlenmiş olup anketler acenta yöneticileriyle yüz yüze görüşme yoluyla yapılmıştır.

\section{Araştırmanın Sınırlılıkları}

Giresun ili genelinde faaliyet gösteren seyahat acentalarının sayısının az olması ve Türkiye'nin içinde bulunduğu küresel Covid 19 salgını nedeniyle bazı seyahat acentalarının faaliyetlerine ara vermesi, ilde faaliyet gösteren 10 (on) işletme ile iletişim kurulabilmiş olması araştırmanın sınırlılı̆̆ını oluşturmaktadır.

\section{Araştırmanın Analizi}

Çalışmada Çok Kriterli Karar Verme Yöntemlerinden biri olan Analitik Hiyerarşi Süreci Yöntemi kullanılmıştır. Analitik Hiyerarşi Süreci yöntemi, 1970'li yıllarda Thomas L. Saaty tarafından geliştirilmiş karar problemlerinin çözümünde kullanılan analiz yöntemidir. AHP, çok yönlü karar verme süreçlerinde karar vericilerin fikirlerini göstermek için kullanılmakta ve problemin hedefi, kriterleri, alt kriterler ve alternatifler arasındaki bağlantıyı gösteren bir hiyerarşik bir 
model oluşturmaktadır (Uğur ve Sarığlu Uğur, 2019: 264). AHP, karar vericinin karar alternatiflerini sıralaması, ikili karşılaştırma yapması ve aralarından en iyisini seçmesi için uygulanan etkili bir yöntemdir. Bu yöntemin karmaşık ve çok boyutlu problemlerin çözümünde anlaşılırlığının kolay olması nedeniyle çok tercih edilen yöntemler arasında yer almaktadır. AHP, araştırmacı tarafından önceden belirlenen faktörler arasındaki önceliklendirme ve öngörüyü önem düzeyleri açısından durumunu ortaya çıkarmayı amaçlayan bir analiz yöntemidir (Yiğit ve Demirtaş, 2020: 308).

AHP yöntemindeki uygulama aşamaları aşağıda belirtilen şekilde sıralanmaktadır:

1. Adım: Hiyerarşik Yapı Oluşturulması: AHP yönteminde ilk olarak problemin çözümü için hiyerarşik bir yapı oluşturulmalıdır. Bu yapı da çalışmanın amacı belirlendikten sonra bu amaç doğrultusunda uygun kriterler seçilmelidir. Çalışma ile ilgili birden çok kriter belirlenebileceği gibi bu kriterlerin alt kriterlerinin olabilmesi de mümkündür (Tulga, Çeliker ve Yağız, 2016: 193).

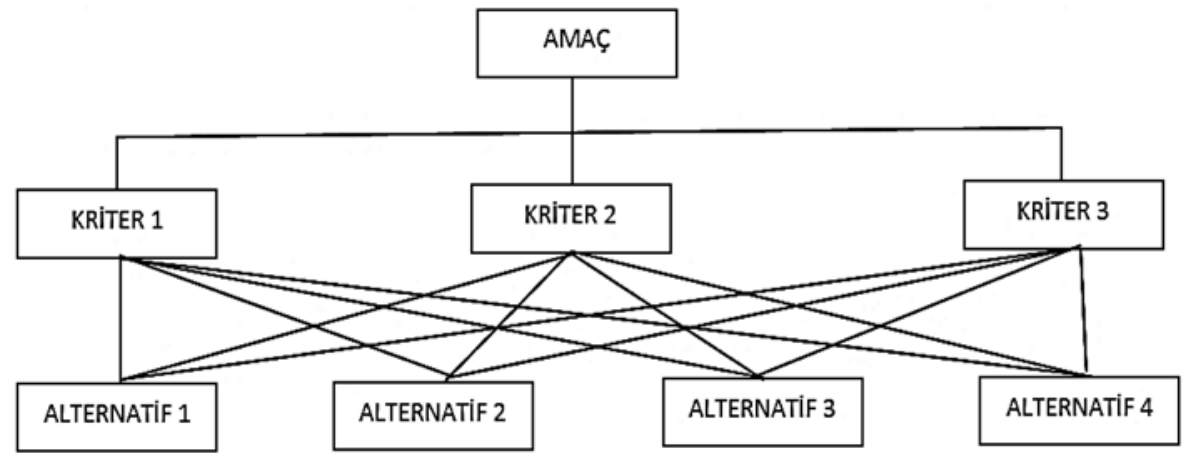

Şekil 2. AHP'de kullanılan temel hiyerarşik yapı (Erdal ve Korucuk, 2018: 102).

2. Adım: Önceliklerin belirlenmesi: Hiyerarşik yapı oluşturulduktan sonra ikinci aşama olarak ikili karşılaştırmalar matrisi yapılmaktadır. İkili karşılaştırma matrisinde kriterin birbiriyle oranlanması hedeflenmektedir (Erdal ve Korucuk, 2018: 105).

Tablo 2. İkili Karşılaştırma Matrisi

\begin{tabular}{|c|c|c|c|c|c|}
\hline & Kriter 1 & Kriter 2 & Kriter 3 &.$\quad$. & Kriter n \\
\hline Kriter 1 & 1 & a 12 & a 13 &.$\quad$. & a 1n \\
\hline Kriter 2 & a 21 & 1 & a 23 & . . & a $2 n$ \\
\hline Kriter 3 & a 31 & a 32 & 1 &.$\quad$. & a $3 n$ \\
\hline Kriter $\mathrm{n}$ & $\mathrm{a} n 1$ & $a_{n} 2$ & $a_{n} 3$ & . . & 1 \\
\hline
\end{tabular}

Saaty (1980) tarafından geliştirilen 1-9 önem ölçeğinde kriterler; eşit öneme sahip olduğunda 1, aşırı derecede öneme sahip olduğunda ise 9 değerini almaktadır. Bu durum Tbalo-3'te gösterilmektedir. 
Tablo 2. AHP Ölçeği Önem Dereceleri Tablosu

\begin{tabular}{ccc}
\hline Önem Derecesi & Tanım & Açıklama \\
\hline 1 & Eşit derecede önemli & Eşit öneme sahip iki kriter \\
\hline 3 & Orta derece önemli & Bir kriterin diğerinden biraz önemli olması durumu \\
\hline 5 & Kuvvetli derecede önemli & Bir kriterin diğerinden fazla önemli olması durumu \\
\hline 7 & Çok kuvvetli derecede önemli & Bir kriterin diğerinden çok fazla olması durumu \\
\hline 9 & Mutlak derecede önemli & Bir kriterin diğerinden aşırı derecede fazla olması \\
& & durumu \\
\hline $2,4,6,8$ & Ara değerler & Yukarıda belirlenen önem derecelerinin ara değerleri \\
\hline
\end{tabular}

3. Adım: Özvektörün Belirlenmesi: İfade edilen kriterlerin yüzde önem dağılımlarının ortaya çıkarılması için, sütün vektörlerinden faydalanılmaktadır. " $\mathrm{n} \times \mathrm{n}$ " türünde B sütun vektörü oluşturulmaktadır. B sütun vektörlerinin hesaplanmasında ise aşağıda yer alan denklem 1'de kullanilmaktadır (Saaty, 1994: 21).

Denklem 1

$$
b_{i j}=\frac{a_{i j}}{\sum_{i=1}^{n} a_{i j}}
$$

n sayıdaki B sütun vektörü, matris formatında düzenlenerek C matrisi elde edilmektedir.

$$
C=\left[\begin{array}{cccc}
c_{11} & c_{12} & \ldots & c_{1 n} \\
c_{21} & c_{22} & \ldots & c_{2 n} \\
\cdot & & & \cdot \\
\cdot & & & \cdot \\
\cdot & & & \cdot \\
c_{n 1} & c_{n 2} & \ldots & c_{n n}
\end{array}\right]
$$

Oluşturulan C matrisi ile birlikte kriterler arasındaki önem değerlerini ortaya çıkaran yüzde önem dağılımları bulunmaktadır. Bu sonuca ulaşılabilmesi için Denklem 2'den faydalanılarak satır bileşenlerinin aritmetik ortalamasının alınması gerekmektedir. Öncelik Vektörü olarak belirtilen $\mathrm{W}$ sütun vektörüne ulaşılmaktadır.

Denklem 2

$$
w_{i}=\frac{\sum_{j=1}^{n} c_{i j}}{n}
$$

4. Adım: Tutarlılık Oranının Hesaplanması: AHP yöntemi, elde edilen Tutarlılık Oranı (CR) hesaplanması, her matris için, özdeğer vektörü ve maksimum özdeğer hesaplanmaktadır. Sonrasında tutarlılık göstergesi CI hesaplanır. CR hesaplamasının temelini kriter sayısı ile Temel Değer adı verilen ( $\lambda$ )bir katsayının karşılaştırılmasıdır. $\lambda$ 'nın hesaplanması için öncelikle A karşılaştırma matrisi ile $\mathrm{W}$ öncelik vektörünün matris çarpımından $\mathrm{D}$ sütun vektörünü elde edilmektedir.

Denklem 3'de belirtilen, elde edilen D sütun vektörü ile $W$ sütun vektörünün karşılıklı elemanlarının bölümünden her bir değerlendirme kriterine ilişkin temel değer (E) elde 
edilmektedir. Bu değerlerin aritmetik ortalaması Denklem 4 ise karşılaştırmaya ilişkin temel değeri $(\lambda)$ vermektedir.

Denklem 3

$$
D=\left[\begin{array}{cccc}
a_{11} & a_{12} & \ldots & a_{1 n} \\
a_{21} & a_{22} & \ldots & a_{2 n} \\
\cdot & & & \cdot \\
\cdot & & & \cdot \\
\cdot & & & \cdot \\
a_{n 1} & a_{n 2} & \ldots & a_{n n}
\end{array}\right] x\left[\begin{array}{c}
w_{1} \\
w_{2} \\
\cdot \\
\cdot \\
\cdot \\
w_{n}
\end{array}\right]
$$

Denklem 4

$$
C I=\frac{\lambda-n}{n-1}
$$

$\lambda^{\prime \prime}$ değerinin hesaplanmasının ardından Tutarlılık Göstergesi (CI), Denklem 5 ile hesaplanır.

Denklem 5

$$
\lambda=\frac{\sum_{i=1}^{n} E_{i}}{n}
$$

En son aşamaya gelindiğinde ise CI, Random Gösterge (RI) olarak ifade edilen standart düzeltme değerine bölünür, Denklem 6 ile CR değeri elde edilir.

Denklem 6

$$
C R=\frac{C I}{R I}
$$

Bununla birlikte, çalışmada verilen cevapların tutarlı olduğuna yönelik olarak veriler elde edilmesi gerekmektedir. AHP yöntemi ile analizler sonucunda CR değerinin 0,1'den küçük olması, ankete cevap veren katılımcıların tutarlı biçimde cevap verdiğini ve çalışmanın güvenilir olduğunu göstermektedir. CR değerinin 0,10'den büyük çıkması durumunda AHP yöntemindeki bir hesaplama hatasını olduğunu ya da ankete katılanların tutarsız cevaplar verdiklerini göstermektedir. Bu nedenlerden dolayı AHP analizinin tekrar yapılması söz konusu olabilmektedir (Saaty, 1980; Karaatlı ve Davras, 2014).

\section{BULGULAR}

Çalışmanın bulgular bölümünde öncelikle anket verileri doğrultusunda seyahat acentası yöneticilerinin demografik özellikleri SPSS25 programı kullanılarak yapılmıştır (Tablo-3). Frekans analizinden sonra Analitik Hiyerarşi Yöntemi (AHP) önceden belirtilmiş olan kriterlerin ikili karşılaştırma matrisi oluşturulmuştur. Sonrasında geometrik ortalamaları alınarak elde edilen bulgular "Super decision V 3.2." programı kullanılarak sunulmaktadır.

Çalışmada elde edilen bilgiler ışığında demografik bilgilere yönelik olarak elde edilen veriler, Tablo 3'te sunulmaktadır. 
Tablo 3. Demografik Özelliklere İlişkin Frekans Dağılımı

\begin{tabular}{|c|c|c|c|}
\hline & Değişken (n: 10) & Frekans & $\%$ \\
\hline \multirow{2}{*}{ Cinsiyet } & Kadın & 3 & 30 \\
\hline & Erkek & 7 & 70 \\
\hline \multirow{5}{*}{ Yaş } & $20-29$ & 2 & 20 \\
\hline & $30-39$ & 3 & 30 \\
\hline & $40-49$ & & 0 \\
\hline & $50-59$ & 3 & 30 \\
\hline & 60 ve üstü & 2 & 20 \\
\hline \multirow{9}{*}{ Eğitim durumu } & Lise öncesi & & 0 \\
\hline & Turizm Lisesi & & 0 \\
\hline & Diğer Lise & 3 & 30 \\
\hline & Üniversite Turizm & & 0 \\
\hline & Üniversite Diğer Bölümler & 5 & 50 \\
\hline & Yüksek Lisans Turizm & & 0 \\
\hline & Yüksek Lisans Diğer Bölümler & 2 & 20 \\
\hline & Doktora Turizm & & 0 \\
\hline & Doktora Diğer Bölümler & & 0 \\
\hline \multirow{5}{*}{$\begin{array}{l}\text { Turizm sektöründeki } \\
\text { çalışma yılı }\end{array}$} & $0-5$ y1l & 1 & 10 \\
\hline & $5-10$ y1l & 1 & 10 \\
\hline & $10-15$ yil & 2 & 20 \\
\hline & $15-20 \mathrm{yll}$ & 3 & 30 \\
\hline & 20 yıl ve üstü & 3 & 30 \\
\hline \multirow{5}{*}{$\begin{array}{c}\text { Seyahat Acentası } \\
\text { yöneticiliği tecrübe yılı }\end{array}$} & $0-5$ y1l & 2 & 20 \\
\hline & $5-10$ yil & 1 & 10 \\
\hline & $10-15$ yıl & 2 & 20 \\
\hline & $15-20$ yıl & 3 & 30 \\
\hline & 20 yıl ve üstü & 2 & 20 \\
\hline \multirow{3}{*}{$\begin{array}{c}\text { Seyahat Acentası çalışma } \\
\text { alanı }\end{array}$} & Bölgesel & 3 & 30 \\
\hline & Ulusal & 3 & 30 \\
\hline & Uluslararası & 4 & 40 \\
\hline
\end{tabular}

Tablo 3'e göre araştırmaya katılan seyahat acentası yöneticileri cinsiyet değişkenine göre 3'ü (\%30) kadın yönetici, (\%70) 7'si erkek yönetici olarak belirlenmiştir. Yaş değişkenine göre ise (\%20) 2'si 20-29 ve 60 ve üstü yaş arası, (\%30) 3'ü 30-39 ve 50-59 yaş aralığında olduğu görülmektedir. 40-49 yaş aralığında ise katılımcı bulunmaktadır. Katılımcıların eğitim durumu (\%50) 5'i üniversite diğer bölümler, (\%30) 3'ü diğer lise, (\%20) 2'si ise yüksek lisans diğer bölümler oluşturmaktadır. Katılımcıların turizm sektöründeki çalışma yılı (\%30) 3'ü 15-20 yıl ve 20 yıl ve üstü, (\%20) 2'si 10-15 yıl, (\%10) 1'i ise 0-5 yıl ve 5-10yıl arasındadır. Katılımcıların seyahat acentası yöneticiliği tecrübe değişkenine göre; (\%30) 3'ü 10-15 yıl, (\%20) 2'si 0-5 yıl, 15-20 yıl ve 20 yıl ve üstü, (\%10) 1'i 5-10 yıl arasında dağılmaktadır. Seyahat acentalarının çalışma alanı 
değişkeni ise (\%40) 4'ü uluslararası, (\%30) 3’ü bölgesel ve ulusal olmak üzere faaliyet göstermektedir.

Çalışma sonucunda elde edilen verilere göre AHP yöntemi ile yapılmış olan analizler sonucunda ikili karşılaştırmalar matrisi Tablo-4'te verilmektedir.

Tablo 4. İkili Karşılaştırmalar Matrisi

\begin{tabular}{|c|c|c|c|c|c|c|c|c|c|}
\hline & Ulaşım & Fiyat & $\begin{array}{l}\text { Doğal } \\
\text { Yaşam }\end{array}$ & İklim & $\begin{array}{c}\text { Külttürel } \\
\text { Yap1 }\end{array}$ & $\begin{array}{c}\text { Coğrafi } \\
\text { Özellikleri }\end{array}$ & Güvenlik & $\begin{array}{l}\text { Alt } \\
\text { Yap1 }\end{array}$ & $\begin{array}{l}\text { Turizm } \\
\text { Tesisleri }\end{array}$ \\
\hline Ulaşım & 1,00 & 4,70 & 1,07 & 3,16 & 0,91 & 1,35 & 0,18 & 0,95 & 0,20 \\
\hline Fiyat & 0,21 & 1,00 & 0,28 & 0,56 & 0,38 & 0,32 & 0,17 & 0,60 & 0,19 \\
\hline $\begin{array}{l}\text { Doğal } \\
\text { Yaşam }\end{array}$ & 0,63 & 2,43 & 1,00 & 3,97 & 1,72 & 4,51 & 0,26 & 2,05 & 0,31 \\
\hline İklim & 0,32 & 1,79 & 0,25 & 1,00 & 0,53 & 0,34 & 0,11 & 0,64 & 0,17 \\
\hline $\begin{array}{l}\text { Kültürel } \\
\text { Yap1 }\end{array}$ & 1,62 & 2,65 & 0,58 & 1,89 & 1,00 & 1,98 & 0,27 & 2,00 & 0,19 \\
\hline $\begin{array}{l}\text { Coğrafi } \\
\text { Özellikleri }\end{array}$ & 0,74 & 3,13 & 0,33 & 1,90 & 0,52 & 1,00 & 0,17 & 1,25 & 0,18 \\
\hline Güvenlik & 5,52 & 5,80 & 3,83 & 9,00 & 3,74 & 5,80 & 1,00 & 5,66 & 5,52 \\
\hline Alt Yap1 & 1,05 & 1,66 & 0,72 & 1,55 & 0,50 & 0,80 & 0,18 & 1,00 & 0,42 \\
\hline $\begin{array}{l}\text { Turizm } \\
\text { Tesisleri }\end{array}$ & 4,94 & 5,20 & 3,27 & 5,70 & 5,38 & 5,38 & 0,18 & 2,31 & 1,00 \\
\hline
\end{tabular}

İkili karar matrisi Tablo 4'den yararlanılarak her hücrenin kendi sütun toplamına bölünmesi ile Tablo 5'de yer alan kriterlerin ağırlıkları elde edilmiştir.

Tablo 5. Kriterlere Göre Ağırlıkların Belirlenmesi

\begin{tabular}{|c|c|c|c|c|c|c|c|c|c|}
\hline & Ulş. & Fiy. & $\begin{array}{l}\text { Doğ. } \\
\text { Yaş. İkl. }\end{array}$ & $\begin{array}{c}\text { Kültürel } \\
\text { Yapı }\end{array}$ & $\begin{array}{l}\text { Coğrafi } \\
\text { Özel. }\end{array}$ & Güven. & Alt Yap1 & $\begin{array}{l}\text { Turizm } \\
\text { Tesisleri }\end{array}$ & $\begin{array}{l}\text { Önem } \\
\text { Düzeyi }\end{array}$ \\
\hline Ulaşım & 0,0624 & 0,1658 & $0,0944 \quad 0,1100$ & 0,0621 & 0,0626 & 0,0718 & 0,0578 & 0,0247 & 0,0791 \\
\hline Fiyat & 0,0133 & 0,0353 & $0,02460,0194$ & 0,0258 & 0,0149 & 0,0683 & 0,0366 & 0,0235 & 0,0291 \\
\hline $\begin{array}{l}\text { Doğal } \\
\text { Yaşam }\end{array}$ & 0,0395 & 0,0856 & $0,0883 \quad 0,1382$ & 0,1172 & 0,2099 & 0,1034 & 0,1247 & 0,0384 & 0,1050 \\
\hline İklim & 0,0197 & 0,0632 & $0,02220,0348$ & 0,0362 & 0,0158 & 0,0440 & 0,0391 & 0,0209 & 0,0329 \\
\hline $\begin{array}{l}\text { Kültürel } \\
\text { Yap1 }\end{array}$ & 0,1010 & 0,0933 & $0,05140,0656$ & 0,0682 & 0,0924 & 0,1060 & 0,1216 & 0,0227 & 0,0802 \\
\hline $\begin{array}{l}\text { Coğrafi } \\
\text { Özellikler }\end{array}$ & 0,0464 & 0,1104 & $0,02890,0662$ & 0,0352 & 0,0466 & 0,0683 & 0,0757 & 0,0222 & 0,0555 \\
\hline Güvenlik & 0,3440 & 0,2045 & $\begin{array}{lll}0,3384 & 0,3132 \\
\end{array}$ & 0,2547 & 0,2700 & 0,3962 & 0,3435 & 0,6739 & 0,3487 \\
\hline Altyap1 & 0,0656 & 0,0585 & $0,06350,0540$ & 0,0340 & 0,0373 & 0,0701 & 0,0607 & 0,0516 & 0,0550 \\
\hline $\begin{array}{l}\text { Turizm } \\
\text { Tesisleri }\end{array}$ & 0,3082 & 0,1832 & $0,28830,1985$ & 0,3666 & 0,2504 & 0,0718 & 0,1403 & 0,1222 & 0,2144 \\
\hline
\end{tabular}

Not. $C R=0,064126066$ 
Çalışmanın analizi sonucunda kriterler arasındaki önceliklendirmeler aşağıdaki Tablo 6'da belirtilmektedir.

Tablo 6. AHP Yöntemi ile Temel Kriterlerin Önem Derecesi Sıralaması

\begin{tabular}{lll}
\hline Kriter & Önem Derecesi Sıralaması & \\
\hline 1 & Güvenlik & $(0,3487)$ \\
\hline 2 & Turizm Tesisleri & $(0,2144)$ \\
\hline 3 & Doğal Yaşam & $(0,1050)$ \\
\hline 4 & Kültürel Yapı & $(0,0802)$ \\
\hline 5 & Ulaşım & $(0,0791)$ \\
\hline 6 & Coğrafi Özellikler & $(0,0555)$ \\
\hline 7 & Altyapı & $(0,0550)$ \\
\hline 8 & İklim & $(0,0329)$ \\
\hline 9 & Fiyat & $(0,0291)$ \\
\hline
\end{tabular}

Önem düzeyi sütunu; ulaşım, fiyat, doğal yaşam, iklim, kültürel yapı, coğrafi özellikler, güvenlik, alt yapı ve turizm tesisleri kriterlerinin sütunlardaki değerlerin ortalaması alınarak elde edilmiştir. CR değeri 0,064126066 olarak tespit edilerek 0,10 değerinden küçük olduğu için Tablo 14 'deki ikili karşılaştırma matrisinin tutarlı olduğu görülmektedir. Önem düzeyi matrisine göre, Güvenlik kriterinin en önemli $(0,3487)$ kriter olduğu sonrasında sırasıyla Turizm Tesisleri $(0,2144)$, Doğal Yaşam $(0,1050)$, Kültürel Yapı $(0,0802)$, Ulaşım $(0,0791)$, Coğrafi Özellikler $(0,0555)$, Altyap $(0,0550)$, İklim $(0,0329)$ son olarak Fiyat $(0,0291)$ kriterleri belirlenmiştir.

Araştırma verileri sonucunda kriterlerin önem derecelerine göre sıralanması ile "güvenlik" kriterinin en önemli kriter olduğu belirlenmiştir. Bununla birlikte, turizm tesislerinin yetersizliği ve doğal yaşama verilen önem diğer önemli sonuçlar olarak elde edilmiştir. Elde edilen sonuçlarda "fiyat" durumunun ekoturizm üzerinde etkili bir kriter olmadığı sonucu ortaya çımıştır. Bu durum, ekoturizm üzerinde temel etkenin günümüz pandemi sürecinin de etkisi ile güvenlik algısının en temel ekoturizm kriteri olduğunu ve fiyatların turistik talepte etkisinin az olduğu sonucuna ulaşılmasını ortaya koymaktadır. Seyahat acenta yöneticileri açısından ekoturizm alanlarının güvenliği, turistik tesislerinin durumu ve doğal yaşam unsurlarının korunması gibi kriterlerin önem arz ettiği sonucuna ulaşılmıştır.

\section{TARTIŞMA, SONUÇ ve ÖNERILLER}

Ekoturizm, değişen yaşam koşulları ile birlikte diğer turizm çeşitlerine göre farkındalığı her geçen gün artan, özellikle de turistlerin beklenti ve ihtiyaçları doğrultusunda son günlerde önemli ölçüde tercih edilmektedir. Odak noktası doğa olan ekoturizm; günümüzde küçük gruplar halinde, kalabalık olmayan ortamlarda ve sürdürülebilir çevre bilincine sahip olarak yapılması turist tercihlerini oldukça etkilemektedir.

Giresun ili ekoturizm potansiyeli açısından değerlendirildiğinde; doğal alanları, koruma altındaki tabiat parkları, akarsuları, şelaleleri, eşsiz yaylaları, ekoturizm köyleri ve bu alanlarda sunulan ekoturizm faaliyetleri ile dikkat çekmektedir. Her ne kadar Giresun doğal güzellikleri ile dikkat çekici unsurlara sahip olsa da ilin potansiyelini ortaya çıkarmaya yönelik olarak yapılmış akademik veya toplumsal çalışmaların sayısı yeterli seviyede değildir. Bu kapsamda ekoturizm destinasyonlarında gerçekleştirilen turizm faaliyetlerini etkileyen kriterlerin (ulaşım, fiyat, doğal yaşam, iklim, kültürel yapı, coğrafi özellikler, güvenlik, altyapı ve turizm tesisleri) önceliklendirilmesi amacıyla Giresun'da faaliyet gösteren seyahat acentalarının yöneticilerine 
ekoturizm anlayışına yönelik olarak kriterler seçimi için anket uygulaması sonucu elde edilen analiz verilerine göre aşağıdaki sonuçlara ulaşılmıştır:

- Destinasyonda bulunan seyahat acentası yöneticilerinin cinsiyet değişkeni incelendiğinde yöneticilerin \%30'unu kadın yöneticiler oluşturmakta olup, kadın yönetici sayısının erkek yönetici sayısına göre daha az olduğu görülmektedir.

- Yaş değişkeni incelendiğinde yöneticilerin 30-59 yaş aralığında (\%60) yoğunluk olduğu görülmektedir. 20-29 (\%20) ve 60-üstü (\%20) yaş aralıklarında eşit sayıda katılımcı olduğu, 40-49 yaş aralığında ise katılımcı bulunmadığı görülmektedir.

- Katılımcıların eğitim durumu incelendiğinde eğitimlerinin turizm alanında olmadığı görülmüş ve \%50'sinin üniversite, \%30'unun lise, \%20'sinin ise yüksek lisans mezunu tespit edilmiştir.

- Katılımcıların turizm sektöründeki çalışma yılı incelendiğinde yoğunluğa sahip olan \%60'lık bölümü 15 yıl ve üstü deneyime sahip grubun oluşturduğu görülmektedir.

- Katılımcıların seyahat acentası yöneticiliği tecrübe değişkenine göre; \%80'inin 10 yıldan daha fazla süredir yönetici olarak çalıştığı görülmektedir.

- Seyahat acentası çalışma alanı değişkeni ise \%40'ı uluslararası, \%30'unun bölgesel ve diğer $\% 30$ 'u ise ulusal olarak faaliyet göstermektedir.

- Sıralama sonuçlarına göre en önemli kriterin güvenlik kriteri olduğu tespit edilmiştir.

- Önem derecesine göre kriterler incelendiğinde ikinci kriterin Turizm Tesisleri olduğu görülmektedir. Diğer önemli kriterler ise sırasıyla doğal yaşam, kültürel yapı, ulaşım, coğrafi özellikler, altyapı ve fiyat olarak belirlenmiştir.

Giresun'da faaliyet gösteren seyahat acenta yöneticilerinin ekoturizm algılamalarının tespitine yönelik olarak elde edilen bulgular sonrasında, aşağıda belirtilen öneriler geliştirilmiş ve maddeler halinde ifade edilmiştir:

- Giresun ilinde hizmet veren seyahat acentası yöneticilerinin ekoturizm faaliyetlerine yönelik olarak en çok önem verdikleri kriterin güvenlik olduğu görülmektedir. Söz konusu kriterin bu kadar önemli görülmesinin nedenleri arasında bugün içinde bulunduğumuz salgın sürecinin etkili olabileceği düşünülmektedir. Terör olaylarının Giresun ekoturizm destinasyonlarında çok nadir olarak görülmesine rağmen, kolluk kuvvetlerinin bu destinasyonların yoğun olarak turist çektiği zamanlarda daha fazla tedbir alması, güvenlik konusundaki endişeleri ortadan kaldıracaktır.

- Giresun ekoturizm destinasyonlarında doğa temelli tesislerin sayısının oldukça azdır. Giresun ilinin sahip olduğu ekoturizm potansiyelini ortaya çıarabilecek yeni tesislerin kurulmasına ve mevcut tesislerin iyileştirilmesine yönelik girişimlerin kamu kurum ve kuruluşları ile özel sektör temsilcileri tarafından desteklenmesine yönelik çalışmaların yapilması gerekmektedir.

- Demografik göstergelerin sonucunda sektörde çalışan kadın yönetici sayısının erkek yönetici sayına oranla düşük seviyede olduğu görülmektedir. Bu bağlamda, özellikle ekoturizm kırsalında yer alan kadın girişimcilere yönelik teşviklerin ve eğitimlerin artırılmasının faydalı olacağ düşünülmektedir.

- Ekoturizm destinasyonlarında iklim ve coğrafya önemli bir sonuç olarak üst sıralarda yer almamasına rağmen, Giresun ilinde ekoturizmin geliştirilmesi için iklimin uygun olduğu zamanlarda turistik aktivitelerin yoğunlaştırılması turistik talep açısından daha uygun olacaktır. Elde edilen sonuçlarda coğrafi yapının etkili bir faktör olmadığı sonucu çıkmış olsa da bu durum ulaşım imkanlarını etkilemektedir. Giresun ili ekoturizm destinasyonlarındaki günümüzün en temel sorunu ulaşımdır. Ulaşım imkanlarının arttırılması ve bu destinasyonlara giden yolların bir an önce düzeltilmesi gerekmektedir. 
- Acenta yöneticilerinin eğitim göstergeleri incelendiğinde hiçbir yöneticinin turizm alanında herhangi bir eğitiminin bulunmadığı görülmektedir. Bu konuda yapılacak ve değiştirilecek bir durum olmayacağından, yıllardır bu sektörde çalışan bu yöneticilere akademik bir vizyon kazandırılması için kamu yönetimlerince bilgilendirme toplantıları ve eğitimler verilmesi uygun olacaktır.

- Giresun'da ekoturizm faaliyetlerinin geliştirilmesinde ve sürdürülebilir bir yapıya kavuşturulmasında, destinasyon noktalarında hartamalı evler ve serenderler gibi geleneksel ekolojik mimari örnekler yapılmalıdır. Bununla birlikte, ekoturizm çiftliklerinin kurulmasına yönelik destekler ve teşvikler sağlanarak, bu çiftliklerin ekoturizmden gelir elde etmek isteyen insanlara öneminin anlatılması uygun olacaktır. Böylelikle, il genelindeki turizm faaliyetlerinin tüm yıla yayılmasına önemli bir katkı sağlanabilme imkanı doğacaktır.

- Ekoturizm destinasyonlarının tanitım ve pazarlama faaliyetlerine yönelik festivaller bulunmasına rağmen, ekoturizm festivali adıyla oluşturulmuş bir festivale rastlanmamıştır. Tanıtım açısından yetersizlikler tüm özel ve kamu kurumları tarafından giderilmeli ve işbirliği içerisinde tanıtım faaliyetleri yapılmalıdır. Sosyal medya ve iletişim araçlarından çok daha fazla yararlanmak gerekmektedir.

Sürdürülebilir çevre anlayışına sahip olan ekoturizm destinasyonların potansiyellerinin ortaya çıkarılması ve dikkat çekebilmesi için ekoturizm destinasyonlarının pazarlama faaliyetlerine, destinasyon imajına, destinasyon markası oluşturulmasına, destinasyon sadakatine ve destinasyon sürdürülebilirliğine önem verilmesi gerekmektedir. Günümüzde hızla değişmekte olan Dünya şartlarının toplum üzerinde oluşturduğu etkiler göz önüne alındığında canlı yaşamının sürdürülebilirliğini hedefleyen ekoturizmin algılanmasına ve bilinçlendirilmesine yönelik olarak öncelikle ilgili bakanlıklar, üniversiteler, akademisyenler, konuya ilgi duyan araştırmacılar olmak üzere hepimize önemli görevler düşmektedir. Ayrıca ekoturizm kapsamında literatürdeki eksikliğin kapatılmasında farklı grupların görüşleri alınarak yapılacak yeni çalışmaların önemli katkı sağlayacağı düşünülmektedir. Ekoturizmden elde edilmesi beklenen gelirlerin arttırılması ancak turizm sektöründe doğrudan katkıda bulunan sektör temsilcilerinin görüşleri tespit edilerek, analiz edilip, sonuçlarının net olarak ortaya konulması suretiyle mümkün olacaktır.

\section{KAYNAKLAR}

Akova, O. (2016). Turizmin Faydalarını Sürdürme. Cook, R. A., Hsu C., Marqua J. (Ed.), Turizm Konaklama ve Seyahat Isşletmeciliği, içinde (ss. 315-332). (5. Baskı). Ankara: Nobel Akademik Yayıncilik.

Akyurt, H. (2019). Ekoturizm: Türkiye'deki Gelişimi ve Mevcut Durumu. Dinçer, E. S., Sönmez, S., Bostanc1, M., Özçoban, E. (Ed.), Sosyal Beşeri ve İdari Bilimler Alanında Araştırma Ve Değerlendirmeler, içinde (ss. 353-368). Ankara: Gece Akademi.

Atay, L. ve Altınışık, Ö. (2017). Etkinliklerin Destinasyon Markalaşmasına Etkisi: Çanakkale Savaşlarının 100.Yılı Anma Etkinlikleri Örneği, Sosyal ve Beşeri Bilimler Araştırmaları Dergisi, 18(40): 110-128.

Bayer, M. Z. (1992). Turizme Giriş. İstanbul: İstanbul Üniversitesi İşletme Fakültesi Yayınları.

Belber, B. G. (2018). Ekoturizmde Pazarlama Çabaları ve Turist Davranışları. Ankara: Detay Yayıncılık.

Björk, P. (2000). Ecotourism from a conceptual perspective, an extended definition of a unique tourism form, International Journal of Tourism Research, 2: 189-202. 
Bunruamkaew, K. and Murayama, Y. (2011). Site Suitability Evaluation for Ecotourism Using GIS \& AHP: A Case Study of Surat Thani Province, Thailand, Social and Behavioral Sciences, 21: 269278.

Ceballos-Lascurain, H. (1987). The Future of Ecotourism. Mexico Journal, January: 13 -14.

Çeken, H. (2016). Sürdürülebilir Turizm (Temel Kavramlar ve Illkeler). (1. Baskl). Ankara: Detay Yayıncilik.

Darwish, A. and Burns, P. (2019). Tourist Destination Reputation: An Empirical Definition, Tourism Recreation Research, 44(2): 153-162.

Doğan, N. ve Gencan, S. (2013). Seyahat Acentası Yöneticilerinin Bakış Açısıyla En Uygun Otel Seçimi: Bir Analitik Hiyerarşi Prosesi (AHP) Uygulaması. Erciyes Üniversitesi İktisadi ve İdari Bilimler Fakültesi Dergisi, 0(41): 69-88.

Erdal, H. ve Korucuk, S. (2018). İmalat işletmelerinde Yeni Ürün Geliştirme Kriterleri: Karadeniz Bölgesi Örneği, Trakya Üniversitesi Sosyal Bilimler Dergisi, 20(1): 99-112.

Erdoğan, N. (2003). Çevre ve (Eko)Turizm. Ankara: Genel Yayın ve Dağıtım.

Erdoğan, N. (2012). Seyahat Acentalarının Çevresel İlgilerinin Sürdürülebilirlik Bağlamında Değerlendirilmesi. Tarih Kültür ve Sanat Araştırmaları Dergisi, 1(4): 247-265.

Fennell, D. (1999). Ecotourism an Introduction. London and New York: Routledge.

Giresun İl Kültür ve Turizm Müdürlügüu. (2021). Seyahat Acentaları. https://giresun.ktb.gov.tr/TR212426/seyahat-acenteleri.html. [Erişim Tarihi:01.02.2021]

Hacıoğlu, N. (2000). Seyahat Acentacıllğı ve Tur Operatörlüğü. Bursa: Vipaş A.Ş.

İçöz, O. (2000). Seyahat Acentaları ve Tur Operatörlüğ̈̈ Yönetimi, Ankara: Turhan Kitabevi.

Ilgaz Yıldırım, B. ve Güzel, Ö. (2019). Seyahat Acentalarının Turist Rehberi Seçim Kriterlerinin Analitik Hiyerarşi Süreci (AHS) Yöntemi ile Değerlendirilmesi. Anatolia: Turizm Araştırmaları Dergisi, 30(1): 69-81.

Ilgaz, B. ve Kozak, M. (2019). Turistlerin Destinasyon Seçim Kriterlerinin Değerlendirilmesi: AHS ve TOPSíS Uygulaması, Emir, O. (Eds.) 20. Ulusal- 4. Uluslararası Turizm Kongresi, İçinde (496-503). Eskişehir: Anadolu Üniversitesi.

Karaatll, M. ve Davras, G. (2014). Tedarikçi Seçiminde Analitik Hiyerarşi Prosesi ve Hedef Programlama Yöntemlerinin Kombinasyonu: Otel İşletmelerinde Bir Uygulama, Yönetim ve Ekonomi Araştırmaları Dergisi, 12(24): 182-196.

Koçan, N. (2012). Ekoturizm ve Sürdürülebilir Kalkınma: Kızılcahamam-Çamlıdere (Ankara) Jeopark ve Jeoturizm Projesi, Karadeniz Fen Bilimleri Dergisi, 2(4): 69-82.

Ovalı, P. ve Tachir, G. (2015). Eko-Destinasyon Olarak Santorini ve Ekolojik Turizm Potansiyelleri, M.S.Ü. Mimarlik Fakültesi Tasarım ve Kuram Dergisi, 11(20): 35-51.

Saaty, T. L. (1980), The Analytic Hierarchy Process, USA: McGraw Hill.

Saaty T.L. (1994). How To Make A Decision: The Analytic Hierarchy Process? Interfaces, 24(6): 1943.

Tulga, İ., Çeliker, N., ve Yağız, M.K. (2016). Analitik Hiyerarşi Yöntemiyle Destinasyon Seçimine Yönelik Bir Uygulama, Uluslararası Alanya İşletme Fakültesi Dergisi, 8(1): 191-199. 
Türkmen, S. (2018). Eko-Regreasyon. Özkök, F. (Ed.), Ekolojik Ekonomi Bakış Açısıyla Yeşeren Turizm, içinde (ss. 129-144). İstanbul: Paradigma Akademi.

Uğur, U. ve Sarığlu Uğur, S. (2019). Tatilde Nereye Gitsek? Turizmde Analitik Hiyerarşi Süreci Yöntemi ile Destinasyon Seçimi, Türk Turizm Araştırmaları Dergisi, 3(3): 261-270.

Ullah, K.M. and Hafiz, R. (2014). Finding Suitable Locations for Ecotourism Development in Cox's Bazar Using Geographical Information System and Analytical Hierarchy Process, Geocarto International, 29(3): 256-267.

Yiğit, A. ve Demirbaş, M. (2020). Türkiye'de Medikal Turizmin Gelişimine Etki Eden Faktörlerin Swot-Ahs Yöntemi ile Tespit Edilmesine Yönelik Bir Araştırma, Karadeniz Sosyal Bilimler Dergisi, 12(22): 173-192.

Zeppel, H. D. (2006). Indigenous Ecotourism: Sustainable Development and Management. London: Cabi Publishing. 